\title{
0 Senhor está vendo, mas Stálin não: representação do embate ideológico no período da guerra fria na Itália
}

////////////////// Mariarosaria Fabris ${ }^{1}$

1. Doutora em Artes (Cinema) pela Escola de Comunicações e Artes da Universidade de São Paulo, com pós-doutorado na Università di Roma III. Professora aposentada da Faculdade de Filosofia, Letras e Ciências Humanas da USP, onde atuou na área de língua e literatura italiana. E-mail: neapolis@bol.com.br 


\section{Resumo}

O embate ideológico entre esquerda e direita na Itália, durante o período da Guerra Fria, e seus reflexos no campo da representação cinematográfica.

\section{Palavras-chave}

Guerra Fria, La rabbia, Pier Paolo Pasolini, Giovannino Guareschi, Dom Camilo e o nobre Peppone.

Abstract

The ideological fight of Left with Right in Italy, during the Cold War, and its reflections in the domain of cinematographic representation.

\section{Keywords}

Cold War, Rage, Pier Paolo Pasolini, Giovannino Guareschi, Don Camillo's last round. 
2. A expressão "mundo livre" surgiu no início da Guerra Fria para designar a liberdade política e de expressão nos países não alinhados com a União Soviética. Foi empregada por Winston Churchill, em 5 de março de 1946, na conferência que anunciou a divisão da Europa em dois blocos.

3. O autor publicou o argumento no n. 38 da revista Vie Nuove (20 set. 1962) e, posteriormente, no volume Le belle bandiere (1977).
Um documentário de 1963, editado a partir de material de arquivo, algo não muito comum no cinema da Itália naquela época, via lado a lado duas figuras singulares da cena cultural do país: o marxista Pier Paolo Pasolini e o conservador Giovannino Guareschi. Tratavase de La rabbia, projeto articulado por Gastone Ferranti, produtor do cinejornal Mondo libero [mundo livre]. Na concepção inicial, o convite havia sido feito apenas a Pasolini, o qual elaborou, de forma absolutamente poética, uma espécie de salmodia sobre os males que afligiam a humanidade, como sequela do último conflito mundial e como consequência da grande batalha ideológica internacional na qual se defrontavam Estados Unidos e União Soviética: a Guerra Fria $^{2}$. Em réplica à indagação proposta pelo filme - "Por que nossa vida é dominada pelo descontentamento, pela angústia, pelo medo da guerra, pela guerra?” — , Pasolini dizia: "Para responder a essa pergunta, escrevi este filme sem seguir uma ordem cronológica e, talvez, nem uma ordem lógica, mas somente minhas razões políticas e meu sentimento poético" (BORGES, 2008)³.

As vozes do escritor Giorgio Bassani (texto poético, o da placidez) e do pintor Renato Guttuso (locução prosaica, a da invectiva) se alternavam na declamação das geremíades escritas pelo amigo bolonhês, enquanto corriam as imagens de um mundo de humilhados, ofendidos, desesperançados, em cuja "inocente ferocidade" Pasolini vislumbrava a nova religião de uma nova era. Ao som do Adagio, de Tomaso Albinoni, desfilavam trechos filmados sobre a era nuclear e a espacial, o levante húngaro, as lutas no Oriente Médio e pela independência na África, os problemas da 
4. Embora seu nome verdadeiro fosse o diminutivo Giovannino, muitas vezes o escritor foi lembrado como Giovanni.
Índia e de um “país chamado Itália”, a guerra da Coreia, a revolução cubana, a incapacidade de renovação da Igreja Católica e dos movimentos sociais, a decepção causada pelo socialismo soviético, as formas de poder na Inglaterra e nos Estados Unidos, a barbárie do capital e a vulgarização do saber, dominado pela indústria cultural (com destaque para o crescente perigo da televisão), entre outros assuntos. Pasolini valeu-se, ainda, de fotos, quadros e de trechos extraídos de cinejornais tchecos, soviéticos e ingleses, bem como de outros temas musicais, de cantos revolucionários cubanos e argelinos e de canções tradicionais russas.

Gastone Ferranti assustou-se com o resultado apresentado pelo diretor e, para contrabalançar uma visão tão radical, resolveu fazer um novo convite, desta vez ao escritor satírico Giovannino Guareschi ${ }^{4}$ Dessa forma, o cineasta teve de cortar e remontar sua realização. A nova feitura do filme irritou Pasolini, o qual, no fim, aceitou compartilhar a autoria da obra, mas, em 2008, o diretor Giuseppe Bertolucci aventurou-se numa "hipótese de reconstrução" do documentário original de 1963.

A “nova” versão foi realizada, com o apoio do Instituto Luce, da Minerva Rarovideo e da Cinemateca de Bolonha, a partir de uma ideia do poeta Tatti Sanguineti, o qual, ao ler o roteiro original - publicado no primeiro volume de Pasolini per il cinema (2001), organizado por Walter Siti e Franco Zabagli —, percebeu que este era mais longo e apresentava outra estrutura em relação ao filme de 1963. Como o Instituto Luce dispunha dos arquivos de Mondo libero, Sanguineti convenceu Bertolucci a aceitar o desafio. La rabbia di Pasolini: ipotesi di ricostruzione della parte iniziale inedita articulava-se em quatro momentos: a introdução, em que o restaurador explicava os motivos de sua intervenção (2’), a hipotética proposta inicial, reconstruída por meio de imagens de arquivo de Mondo libero e do roteiro original (16’), a parte pasoliniana da edição de 1963 (55') e um apêndice com trechos de jornais de atualidades da época sobre Pasolini (12'). A “reconstrução-simulação” de 2008, no entanto, não agradou a todos, tendo resultado num "filme abortado", na opinião de Anahí Borges (2008), que apontou a seleção do 
5. No original, qualunquismo. Essa questão será retomada mais adiante; as traduções para o português neste artigo foram feitas pela autora.

6. Se, na parte de Pasolini, o texto dividia-se em canto e discurso, como os denominou Hervé JoubertLaurencin (1995, p. 313), na parte de Guareschi, os comentários eram ora sérios, ora satíricos, sendo sua locução confiada a Gigi Artuso e Carlo Romano, respectivamente. material, a montagem e a narração de Giuseppe Bertolucci "referencial, pertencente mais ao jornalismo que à poesia" — como os grandes problemas do filme:

\begin{abstract}
A escolha das imagens de arquivo, e mais ainda, a sua ordem e tempo de montagem destoam da construção poética verdadeira de Pasolini. E, pior do que isso, a narração proposta por Bertolucci é escandalosamente incoerente com o conceito de dor e indignação colocados em cena por Giorgio Bassani e Renato Guttuso na direção de Pasolini.
\end{abstract}

Na reconstrução da parte inicial, eliminada em 1963, a outra voz narradora, que serve de contracanto à de Bertolucci, é do ensaísta e escritor Valerio Magrelli.

Voltando ao filme comercializado na época, enquanto Pasolini, na primeira metade, com sua visão poética e utópica, fazia um verdadeiro ato de acusação à civilização ocidental, Guareschi saía em sua defesa, na segunda parte, dando uma demonstração cabal de seu reacionarismo preconceituoso e de sua intolerância em relação ao outro, o que levou Curzio Maltese (2008) a afirmar que, nesse documentário, o escritor satírico "ofereceu $[. .$.$] o pior$ de seu indiferentismo" 5 .

Ao contrário da desesperada interpretação pasoliniana dos acontecimentos sociopolíticos, religiosos e até mundanos daquele período, Guareschi propunha uma leitura esperançosa, como era afirmado na obra em tela: "Porque, apesar de Mao, Kruschev e dos outros problemas, ainda vale a pena viver neste planeta $[\ldots] \mathrm{e}$, dentro de nós, é mais forte a esperança do que o medo" ${ }^{6}$. Segundo Mario Turello, apesar dessa gritante diferença, havia, em La rabbia, convergências entre os dois autores, na escolha do material e no amor de ambos pela civilização camponesa, em vias de extinção.

La rabbia estreou em 13 de abril de 1963, mas foi um fracasso comercial, ficando apenas alguns dias em cartaz, em pouquíssimas cidades. O documentário só tornou a ser exibido em 1992, na televisão, o que, talvez, explique a pequena fortuna crítica a seu 
7. Bertolucci, também, considerou insustentável a atitude de Guareschi em relação à descolonização da África e à guerra da Argélia, o que o levou a excluir a parte do escritor satírico da nova versão de La rabbia. respeito. No calor da hora, apenas alguns críticos, dentre os quais Alberto Moravia, Mino Argentieri e Edoardo Bruno, ressaltaram a qualidade estética e o valor poético da parte pasoliniana; nos anos 1990, a crítica francesa se debruçou sobre ele; finalmente, em 2005, Paolo Garofolo dedicou um ensaio de fôlego ao longa-metragem: “'La rabbia' di Pier Paolo Pasolini e Giovannino Guareschi. Speranza e disperazione. Convergenze e divergenze". O artigo que Moravia (2010, p. 505-506) escreveu quando do lançamento do filme intitulava-se sintomaticamente "Pasolini nella trappola di Guareschi” [Pasolini na armadilha de Guareschi]:

Temos vergonha, em primeiro lugar, que, nas telas italianas, surja uma série de lugares comuns tão decrépitos e vulgares como os tecidos na parte do filme de autoria de Giovanni Guareschi. Temos vergonha pelos argelinos, pintados como um povo incivil e indigno de ser livre; pelos massais, bantos, uatúsis, iorubas, ibos e todos os demais povos africanos, dos quais Guareschi fala fora de propósito, demonstrando uma ignorância igual à sua estupidez ${ }^{7}$; pelos Estados Unidos e pela União Soviética, juntados no mesmo ódio impotente e ridículo, segundo uma concepção política pequeno-burguesa e nazista, que remonta aos anos ao redor de 1930; por todos os caídos das muitas guerras que pessoas como Guareschi mandaram os italianos combater e sobre os quais o autor de Dom Camilo não hesita em especular com inverídica retórica. E temos vergonha, por fim, logo dele, Giovanni Guareschi, que não se dá conta de ter a cabeça cheia do lixo político de 30 anos atrás.

Vergonha à parte, o filme de Guareschi nada mais é do que propaganda fascista sem a mínima sombra de uma interpretação pessoal. Como sói acontecer, a estupidez e a ignorância são preguiçosas; Guareschi nem tentou confrontar as suas ideias, vamos dizer assim, com a realidade, levar a cabo uma modesta verificação qualquer do fundamento de suas convicções. Diante de tal filme, só se podia responder com a propaganda oposta. Pasolini deveria ter feito ele também um filme impessoal e de propaganda; e, sem dúvida teria sido mais eficaz do que Guareschi, do mesmo modo que a retórica baseada na razão, no fim, é mais eficaz do que a baseada na loucura. Mas Pasolini quis dar uma interpretação 


\begin{abstract}
o mais possível original e pessoal, ou seja, poética, dos acontecimentos destes últimos 15 anos. Ou seja, tentou deslindar pacientemente a intricada complexidade dos fatos para encontrar neles um sentido não convencional, não preestabelecido, não previsível. A sua, mais do que uma interpretação e uma explicação, é uma trabalhosa leitura de um texto sempre obscuro e, às vezes, até mesmo indecifrável. Nessas reconstruções a posteriori é difícil, para não dizer impossível, conseguir ser de todo convincente. [...] Pier Paolo Pasolini fez uma escolha de imagens muito bonitas, consoantes com seu gosto ora austero e cristão, ora barroco e decadente. Quanto ao comentário, o teríamos preferido mais simples, mais direto, mais racional, menos literário.
\end{abstract}

A indignação de Moravia com a postura de Guareschi e seu espanto com a candura do amigo, ao aceitar participar de tal empreitada, justificavam-se ainda mais com a visão dos cartazes e do trailer de La rabbia, feitos para aguçar a curiosidade do público pela disputa ideológica entre os dois autores e, no fundo, endossar as ideias do escritor satírico. Um dos cartazes trazia, à esquerda, a silhueta de Pasolini, de corpo inteiro e vestido como um burguês, diante de uma placa na qual estava escrito "La rabbia de Pier Paolo Pasolini", e, à direita, a silhueta de Guareschi, também de corpo inteiro e vestido como um homem abastado do campo, diante de outra placa com os dizeres "La rabbia de Giovannino Guareschi”. Num outro, um círculo, contendo os rostos de Pasolini (no topo, à direita) e de Guareschi (em baixo, à esquerda), estava circundado por escritas em letras garrafais: "Governantes/politiqueiros/mulheres bonitas/e feias/mitos.../figuras.../e fatos de/nosso tempo/arrastados pelo embate entre o diabo e a água benta/Um filme de PasoliniGuareschi/La rabbia”. E a locução do trailer também insistia nessa contenda entre as duas partes envolvidas:

Filme único e inconfundível/La rabbia/La rabbia é o resultado da mais acesa polêmica/entre dois diretores de ideologias opostas./Um muro sempre os dividiu, um muro não apenas ideológico/mas também real./Assim Pasolini trabalhou sem ter contato com Guareschi/e Guareschi pôde não encontrar Pasolini./E, agora, 
com a palavra, Pasolini,/o homem de esquerda:/“Passe bem, seu Pier Paolo Pasolini”. E este é Giovannino Guareschi,/o homem de direita:/“Prezado Pasolini, eu, burguês de direita,/ao ver um negro degolar um branco,/ digo: pobre branco"./La rabbia oferecerá a possibilidade de ver personagens e acontecimentos/não mais com o olhar exclusivo do sentimento pessoal,/mas com um olhar que analisa as perspectivas desde a esquerda/e outro que as analisa desde a direita,/com o olhar de Pasolini/e o de Guareschi./La rabbia/Um filme sem precedentes/Apaixonante

O discurso do trailer merece alguns comentários. Em primeiro lugar, a insistência com que era sublinhado o choque entre duas visões de mundo, divergência que remetia à primeira página do semanário satírico Candido (criado por Guareschi e Giovanni Mosca em 1945), com suas vinhetas sobre qualquer acontecimento visto desde a esquerda e desde a direita, que serviam para pôr na berlinda os marxistas, conforme as normas mais sórdidas do anticomunismo da época e que, no fundo, não deixaram de ser seguidas também no material publicitário do filme. Entre elas, poderia se pensar no fato de Pasolini, no trailer e nos cartazes, ser quase sempre apresentado vestido como um burguês, ao contrário de seu antagonista, talvez para pôr em evidência o que, aos olhos dos conservadores, devia ser uma contradição. Essa crítica fica bem clara quando Guareschi se declara um burguês de direita, o que deixa subentendido que seu oponente não passava de um burguês também, de esquerda, mas sempre burguês.

Em segundo lugar, a insinuação de uma troca epistolar entre os autores, que nunca existiu, mas foi inventada para promover o documentário, presente nas palavras que os dois trocam no trailer. Nas falsas cartas, Pasolini teria jogado na cara de Guareschi sua mediocridade, seu indiferentismo, sua demagogia e seu humorismo reacionário, e Guareschi teria contestado Pasolini, dizendo, entre outras coisas: "As ditaduras não toleram o humorismo, do qual têm medo, e, na soleira do tétrico e infinito império comunista, a História escreveu com o sangue de milhões de pessoas assassinadas: “Aqui é proibido rir"” (TURELLO, [S.d.]). 
E, por fim, o embaralhamento entre esquerda e direita, realçado não apenas pelas roupas dos protagonistas da contenda mas também no segundo cartaz descrito, em que, pela posição de Guareschi e de Pasolini, o primeiro, com seu rosto carrancudo, encarnaria o diabo, enquanto este, com sua expressão cândida, corresponderia à água benta - hipótese reforçada pelo fato de, no trailer, as palavras de Pasolini virem acompanhadas de uma melodia eclesiástica, enquanto as de Guareschi tinham, como fundo musical, acordes mais incisivos.

Diante disso, entende-se melhor por que Moravia repreendia seu amigo por ter caído na armadilha do escritor satírico, mas, ao mesmo tempo, sem essa ingenuidade do diretor-poeta e, principalmente, sem sua coragem para continuar na empreitada, mesmo quando se deu conta de que talvez tivesse embarcado numa canoa furada, o cinema teria sido privado de uma obra tão singular e expressiva.

Se o nome de Pasolini é largamente conhecido entre nós, o mesmo não acontece com o de Guareschi, embora ele esteja na base de uma das séries mais bem sucedidas da indústria cinematográfica italiana dos anos 1950-1960, a de Dom Camilo e Peppone, na qual, independentemente dos diretores que dirigiram os filmes (praticamente intercambiáveis entre si), a unidade e a continuidade eram asseguradas pelo carisma de seus intérpretes, Fernandel e Gino Cervi: Don Camillo (Dom Camilo, 1951) e Il ritorno di Don Camillo (O regresso de Dom Camilo, 1953), de Julien Duvivier, Don Camillo e l'onorevole Peppone (Dom Camilo e o nobre Peppone, 1955) e Don Camillo monsignore ma non troppo (Dom Camilo monsenhor, 1961), de Carmine Gallone, e Il compagno Don Camillo (O camarada Dom Camilo, 1965), de Luigi Comencini. O sexto filme com o comediante francês e com o ator italiano deveria ter sido Don Camillo e i giovani d'oggi, cuja realização foi interrompida pela morte de Fernandel, em 1971. As filmagens foram retomadas por Mario Camerini no ano seguinte, tendo como protagonistas Gastone Moschin (Dom Camilo) e Lionel Stander (Peppone). 
Outras realizações televisivas e cinematográficas vieram atestar a longevidade do universo criado por Guareschi, uma vez que todas as produções se basearam nos mais de 300 contos que ele começou a escrever em 1945 para as páginas de Candido e a publicar em livros a partir de 1948, quando lançou Mondo piccolo - Don Camillo: a série O pequeno mundo de D. Camillo, com Otello Zeloni (o padre) e Heitor de Andrade (o prefeito), apresentada entre 1954 e 1957 pela TV Tupi; a novela da Rede Globo Padre Tião (1965-1966), inspirada no personagem de Guareschi; outra série da TV Tupi, Dom Camilo e os cabeludos (1971-1972), novamente com Zeloni; os 13 episódios de The little world of Don Camillo, estrelados por Mario Adorf (Dom Camilo) e Brian Blessed (Peppone), que a BBC mandou em onda em 1981, transmitidos também sob o título de Die kleine Welt des Don Camillo, na República Federal da Alemanha (1983) e na Suíça (1985); Don Camillo (1983), filme dirigido e protagonizado por Terence Hill, com Colin Blakely no papel do antagonista.

Do ponto de vista de seu conteúdo ideológico, os filmes da saga protagonizada por Fernandel e Cervi também podem ser considerados intercambiáveis entre si, uma vez que, em todos eles, "o pequeno mundo de Dom Camilo" é sempre o mesmo: o mundo do pequeno-burguês ainda à procura de uma identidade, não mais fascista, mas indiferentista, avesso ao comunismo, sem um papel específico na nova sociedade que vinha se estruturando e que buscava na recuperação de um vago humanismo o caminho para a paz. Um mundo aparentemente à margem das grandes questões nacionais (uma vez que elas eram reduzidas à dimensão do cotidiano e do familiar), no qual as massas populares deveriam continuar excluídas da política, ainda segundo os ditames do fascismo ${ }^{8}$.

8. Leitura, em chave inversa, dos argumentos de Brunetta (1982, p. 489-493).
Ao resenhar O regresso de Dom Camilo, Moravia (2010, p. 177-179) ressaltava como, nesse filme, o embate ideológico entre esquerda e direita era amenizado, quando não neutralizado: 
O gigantesco sucesso do primeiro Dom Camilo, de Duvivier, sem dúvida é uma das operações mais claras desse espírito redutivo em função positiva de abordagem e familiarização. Em palavras simples, Dom Camilo é um sonho, o sonho da burguesia a respeito dos terríveis problemas que dividem a humanidade nos dias de hoje. Em Dom Camilo, a burguesia sonha com um padre armado de metralhadora, brigão, forte, esperto, vitorioso e generoso, diante do qual está um prefeito comunista, ele também violento e brigão, mas menos forte do que o padre, totalmente desarmado do ponto de vista ideológico, puro sentimento e, apesar dele, levado a ceder e a concluir todas as suas revoltas com o sinal da Santa Cruz. Dissemos que Dom Camilo é um sonho e, de fato, não seria difícil demonstrar que, tanto na realidade quanto na história, padres e comunistas como Dom Camilo e Peppone não existem. Mas o ponto não é esse. Graças a esse sonho, em que as coisas são como se gostaria que fossem quando não o são, a burguesia do mundo todo se familiariza com a questão do comunismo, aproxima-se dele, toca-o. A superioridade de Dom Camilo em relação a tantos filmes anticomunistas e, em geral, de viés político, consiste em que, mesmo intermediado pela figura de um marxista camponês e boa-praça, a realidade do comunismo é enfrentada e parcialmente descrita. Assim, o sucesso de Dom Camilo deve-se a vários fatores, mas, principalmente a dois: de um lado, uma descrição quase nova do contraste social e ideológico e, de outro, a redução desse contraste, de outra forma assustador e insolúvel, a uma pequena briga de aldeia, a troca de peças e desfeitas entre um padre simpático e turbulento e um revolucionário não menos simpático e bonachão.

[...] Todo o filme equilibra-se, como o primeiro Don Camilo, na corda estirada daquele espírito redutivo que pode ser resumido no dito popular: "O diabo não é tão feio como parece”. [...] Peppone, talvez, quase não seja mais reconhecível de tão bonzinho que se tornou e de tanto que seu marxismo parece ter-se evaporado; mas, como dissemos, trata-se de um sonho [...].

Ao contrário do romancista, outros críticos, como Gian Piero Brunetta e Gian Franco Vené, viram na saga a abertura de um diálogo entre católicos e comunistas, em virtude da humanização da imagem destes, muito diferente da pintada pela propaganda 
9. A temporada cinematográfica, na Itália, vai de setembro de um ano a agosto do ano seguinte.

10. A tradução correta seria "Dom Camilo e o deputado Peppone". O DVD traz a versão francesa, La grande bagarre de Don Camillo; por isso, seu título em português acabou sendo A grande briga de

Don Camillo.

11. Peppone é o aumentativo de Peppe, uma das formas familiares

para o nome próprio Giuseppe (José). O emprego do sufixo -one e os bastos bigodes do prefeito de Brescello, cidadezinha da Emília-

Romanha, o caracterizavam como um êmulo de Baffone, apelido popular de Stálin na Itália, principalmente depois da II Guerra Mundial. No grande cartaz de propaganda eleitoral, a pose do prefeito lembrava a do líder soviético, até que Dom Camilo, com alguns retoques, o caracterizou como o diabo. norte-americana (BRUNETTA, 1982, p. 489-490). Num discurso na Câmara dos Deputados em 1954, Mario Alicata (BRUNETTA, 1982, p. 490), um dos máximos representantes da política cultural do PCI (Partido Comunista Italiano), assim comentava o enorme sucesso de Dom Camilo:

Esse filme lucrou mais de um bilhão, porque, apesar de tudo, talvez não corresponda às intenções de quem o produziu; quer dizer, um filme facciosamente, estupidamente anticomunista. Em suma, era um filme no qual circulava certo ar que levava a pensar numa possibilidade de pacificação, de distensão.

Vittorio Spinazzola (BRUNETTA, 1982, p. 490) também não deixou de ter uma visão positiva sobre a primeira produção da série:

\begin{abstract}
Dom Camilo obtém um bilhão e meio de lucro e o primeiro lugar absoluto na classificação geral de 1951$52^{9}$, com uma diferença de 500 milhões sobre o segundo colocado, Anna, de Lattuada. Que inesperado mecanismo de massa tinha sido acionado?

Simplesmente tinha acontecido que, num dos países mais politizados do mundo, o público se achava diante de um filme que falava de política e falava dela em termos de atualidade, chamando em causa diretamente os grandes protagonistas da vida coletiva, católicos e comunistas.
\end{abstract}

Diante dessas afirmações surgem duas dúvidas, a serem comentadas à luz de Dom Camilo e o nobre Peppone (cujo DVD foi lançado recentemente no Brasil $^{10}$ ), o único a trazer no título o nome do antagonista $^{11}$. A primeira diz respeito à politização da sociedade italiana. Não se pode esquecer que todos os filmes foram rodados da primeira metade dos anos 1950 em diante; portanto, depois do fatídico pleito de 18 de abril de 1948, quando a Frente Popular - formada pelo PCI e pelo Partido Socialista Italiano de Unidade Proletária - foi excluída do poder, pela esmagadora vitória da DC (Democracia Cristã), que quase alcançou a maioria absoluta, com 48,5\% dos votos, afirmando-se de vez como uma força hegemônica, 
representante da burguesia moderada. Guareschi foi um dos principais artífices da vitória da DC, ao transformar Candido no órgão oficial do partido e ao criar cartazes de propaganda anticomunista, com dizeres do tipo "No segredo da cabine eleitoral, Deus está vendo você, Stálin não" (FERRAZZOLI, [S.d.]), frase retomada por ele no roteiro da produção de 1955. Nesse filme, embora Giuseppe Bottazzi, vulgo Peppone, tivesse conseguido eleger-se deputado, seu partido, a Frente Independente da Paz, havia sido derrotado. História e ficção ostentavam a mesma data, 1948, pois o prefeito, nascido em 1899, tinha na época 49 anos.

A vitória dos democrata-cristãos havia sido arduamente preparada, depois do susto levado com as perdas sofridas numa série de eleições administrativas em fins de 1946, em favor de L'Uomo Qualunque (o homem comum). O partido havia sido fundado no dia 8 de agosto de 1945 por Guglielmo Giannini, que, em 12 de dezembro do ano anterior, tinha lançado, em Roma, o semanário L'Uomo Qualunque. O indiferentismo canalizava os temores da classe média italiana, particularmente a do Sul, a qual, diante da grave situação econômica, do fervilhar de novas ideias políticas e da participação de amplas camadas da população na vida nacional, aspirava à ordem como valor supremo, sobretudo a social, estando insatisfeita com a demora da DC em excluir do governo comunistas e socialistas.

Na opinião de Moravia (2010, p. 177, 487, 618), mais do que expressar o ideário específico de um partido, esse movimento era uma "inclinação psicológica" de seus conterrâneos, resultado da "deterioração do ancestral humanismo italiano", e suas vitórias eleitorais vinham demonstrar não apenas o quanto os princípios do fascismo ainda estavam vivos no imediato pós-guerra, mas, principalmente, o profundo antissocialismo das camadas médias moderadas. Caracterizando-se por uma visão de mundo fragmentária, cristalizada, que se interessava apenas pelo fait divers, o indiferentismo seria uma espécie de "bom senso regressivo", "um estado de espírito", mas de um "espírito redutivo", o qual, em vez de tentar alcançar pensamentos mais elevados, procurava reduzilos ao próprio tamanho. Com fina ironia, o escritor, no entanto, 
não o considerava de todo negativo, na medida em que ajudaria as almas simples a penetrar numa realidade que, de outro modo, não conseguiriam captar, e a familiarizar-se com ela.

A segunda dúvida leva a indagar se a esquerda tinha caído, como acontecerá com Pasolini, na armadilha de Guareschi. Se, de um lado, a palavra de ordem no seio do PCI era distensão, visto o partido estar empenhado em dar um "novo rumo" às suas diretrizes políticas, repudiando manifestações sectárias, de outro, causa espanto que não se percebesse nesse envolvimento afetivo entre as partes focalizadas na saga uma tentativa de homogeneização, na qual o comunismo acabava sendo apresentado como um desvio, temporário, pois, como se concluía em Dom Camilo e o nobre Peppone, o bom filho à casa torna. É muito sintomática, no filme, uma das conversas do pároco com o Cristo crucificado do altarmor de sua igreja. O prefeito, que foi acender um grande círio na paróquia antes das eleições, acabou por esquecer seu chapéu num dos bancos da frente. Dom Camilo estava amassando o chapéu, quando Cristo o repreendeu, pedindo-lhe que o colocasse de volta no banco, como se Peppone o tivesse deixado lá para guardar lugar. $\mathrm{E}$ assegurou-lhe que um dia este voltaria, dentro de dois meses ou dentro de dois anos, mas voltaria, sem se esconder e pela porta principal. Ao que o cura contestou que esse era um sonho lindo.

$\mathrm{E}$, de fato, o prefeito regressou, com outro círio, desta vez carregado por quatro camaradas, para agradecer a graça de ter sido eleito. E não apenas ele frequentava a igreja; Lênin, seu caçulinha, também havia ido pedir uma graça porque seu pai estava sendo processado sob a acusação de ter roubado as galinhas do padre, em represália ao estrago que este fizera a seu material de propaganda. Mais uma vez será a intervenção de Cristo a resolver a situação, mandando Dom Camilo inocentar Peppone, o que ele fará, mas sem deixar de vingar-se de seus inimigos, ao declarar no tribunal que eram todos bons cristãos, pois, embora de dia negassem sua fé, de noite iam implorar o perdão de Deus.

Para completar o quadro, a mulher do prefeito também havia voltado à igreja, anos depois do batizado de seu último filho, para acender uma vela à Virgem Maria, não conseguindo esconder 
seu desgosto pelos boatos sobre o marido e sua secretária, a bela e jovem Clotilde, líder do Comitê Feminino pela Paz, que, quando discursava, lotava o auditório... de homens, atraídos mais por seus dotes físicos do que por suas palavras inflamadas. O idílio, na verdade, havia sido abortado pelo próprio Peppone, mas o padre, ao consolar a esposa do adversário, aproveitou para destilar seu veneno, dizendo-se surpreso, porque aquele tipo de situação era aceito dentro do partido, uma vez que uma jovem mulher era a recompensa dada a quem realizasse uma grande façanha, numa clara alusão à relação entre a parlamentar Nilde Iotti e o Secretário Nacional do PCI, Palmiro Togliatti, casado, pai de um filho e 27 anos mais velho do que sua companheira.

Como se não bastassem essas pequenas vitórias de Dom Camilo, pois será sempre ele a vencer com seu bom senso, havia um ataque maior, que o filme promovia - nas entrelinhas, mas de modo não muito sutil - contra o prefeito e, consequentemente, contra os que compartilhavam sua ideologia, o de ser ignorante. Para poder assumir o novo cargo, Peppone precisava obter o diploma da escola primária. O cenário do exame de admissão será uma inusitada sala de jardim de infância, o que vinha sublinhar a infantilização do personagem. No dia do exame, o prefeito não conseguia resolver o problema de matemática nem sabia como desenvolver o tema da redação, "Um homem que você nunca esquecerá”. A salvação providencial virá do pároco, que lhe dará a solução do problema, em troca da autorização para construir uma nova igreja, e lhe sugerirá que fale dele como homem inesquecível. Desse modo, o público saberá que os dois se conheceram na época da luta contra os nazifascistas, embora na redação, narrada emoff, o prefeito contará os fatos de modo a sublinhar a covardia do padre, enquanto as imagens o desmentirão. O filme voltará a bater na mesma tecla em mais um episódio. Para tirar das terras de um companheiro um tanque escondido lá desde o fim da guerra, que Peppone e seus camaradas acreditavam ser alemão, apesar da grande estrela que o blindado exibia, ele precisará aceitar de novo a ajuda do pároco, pois o carro de combate deveria ter sido entregue às autoridades militares aliadas ao término do conflito, quando foi ordenado o desarmamento dos partisans. Embora o tamanho do armamento 
fosse exagerado, tratava-se de uma nova alusão a fatos relativos ao PCI, o qual, mesmo no período pós-bélico, manteve uma estrutura paramilitar, principalmente no centro e no norte da Itália, pronta para intervir em caso de perigo para os membros do partido, como quase aconteceu por ocasião do atentado a Togliatti, em 14 de julho de 1948. Mais uma vez, foram os sábios conselhos do pai espiritual que permitiram a Peppone enfrentar uma situação da qual não saberia sair sozinho, pois, como uma criança - levada, mas de bom coração - , ele precisava de alguém que lhe indicasse qual era o caminho certo a seguir.

Dessa forma, o filme transformava em mera boutade um dos momentos-chave da história italiana, o da Libertação, quando homens e mulheres, na maioria das vezes bem jovens, pegaram em armas, contando também com a colaboração da população, principalmente no campo, e com a solidariedade de padres de pequenas comunidades e até mesmo de bispos, como atestam relatos de partisans recolhidos no volume Io sono l'ultimo: lettere di partigiani italiani (2012), organizado por Stefano Faure, Andrea Liparoto e Giacomo Papi, e filmes como Roma, città aperta (Roma, cidade aberta, 1944-45), de Roberto Rossellini, e Il sole sorge ancora (O sol ainda se levantará, 1946), de Aldo Vergano, em que padres católicos e combatentes comunistas eram torturados e/ou fuzilados por nazistas.

Apesar da presença de pessoas de várias ideologias na luta pela libertação, a Resistência acabou se tornando patrimônio moral das esquerdas; talvez por isso Dom Camilo e o nobre Peppone preferiu apelar para o sentimento patriótico ligado à Primeira Guerra Mundial, quando, ao conquistar territórios pertencentes ao Império Austro-Húngaro, a Itália completava sua unificação. Enquanto Peppone se dirigia à população no dia das eleições, o cura, para encobrir sua fala, passou a transmitir pelo alto-falante La canzone del Piave, fato que teve um efeito diferente do desejado, uma vez que o prefeito, ao lembrar os acontecimentos dos quais ele também havia sido protagonista, se inflamou e, com seu discurso ufanista, entusiasmou seu eleitorado e o próprio Dom Camilo. 
La canzone del Piave, título popular de La leggenda del Piave, foi o hino oficial da Itália entre 1943 e 1946. Tinha sido composta por E. A. Mario (pseudônimo de Giovanni Ermete Gaeta), no calor da hora, para rememorar a participação da Itália na Primeira Guerra Mundial e celebrar a batalha travada entre as tropas italianas e o exército austro-húngaro às margens do rio Piave (nordeste do país), entre 15 e 23 de junho de 1918. O patriotismo presente em seus versos foi instrumentalizado para fazer esquecer as atrocidades da Grande Guerra e o enorme número de baixas, embora a canção não tivesse deixado de narrá-los.

Levar à comoção ao rememorar o primeiro conflito mundial, e não o segundo, significava aproximar-se da apropriação que o fascismo soube fazer da Grande Guerra, ao glorificar a bravura dos que se bateram para resgatar de mãos inimigas o solo pátrio, e unir a esse sentimento o receio pelo perigo bolchevique, representado pelos ideais do Partido Socialista Italiano, promotor de uma série de agitações no campo e nas cidades, entre 1919 e 1920, o que fez com que parte da população, assustada, desejasse que a lei e a ordem fossem restauradas no país com mão de ferro.

Em Dom Camilo e o nobre Peppone, portanto, o que determinou a eleição do prefeito como deputado não foi o que ele pregava, mas o patriotismo, o que vinha esvaziar sua ideologia. Nesse sentido, o filme estava bem consoante com as diretrizes dos grupos católicos em relação ao papel da sétima arte em prol de seu ideário:

\footnotetext{
Os marxistas, ao oporem a tela ao púlpito nos países em que imperam, transformaram milhares de igrejas em cinemas: é nosso dever defender nossas igrejas e, além disso, é nossa ambição transformar também as telas em púlpitos e, desse modo, fazer dos nossos cinemas filiais de nossas igrejas (PINTO, 1976, p. 12).
}

Poder-se-ia concluir que os dois lados tinham objetivos não muito diferentes a serem alcançados graças a estratégias bem parecidas, uma vez que dogma marxista e moral católica pareciam equivalerse, como havia assinalado o escritor Ignazio Silone (2004, p. 59-60), em 1959, ou seja, 28 anos depois de ter sido expulso do PCI: 
Igreja e Partido Comunista, no campo, são dois vasos comunicantes. [...]

A principal concorrência entre essas duas grandes instituições se dá, no plano local, na base de diversões e brindes. [...]

Isso demonstra a confiança depositada por esses padres na graça divina e por esses comunistas na consciência de classe do proletariado. Mas considerar esses católicos crentes e esses comunistas ateus é apenas uma maneira de dizer convencional, sem mais fundamento algum: estes ferozes antagonistas políticos, se refletirmos bem, são feitos da mesma matéria, são movidos pelos mesmos instintos, têm as mesmas aspirações, acreditam nos mesmos valores, sonham com a mesma coisa: vencer na loteria esportiva, ser rico sem trabalhar.

Ser comunista na Itália daquele período, no entanto, não era um fato tão simples, pois muitos militantes já começavam a questionar as diretrizes do partido e a se angustiarem diante de suas contradições, mesmo antes das revelações de Kruschev (1956). Uma dilaceração que Italo Calvino (2011, p. 5) já havia expressado quatro anos antes, ao publicar $I l$ visconte dimezzato (O visconde partido ao meio) "Estava interessado no problema do homem contemporâneo (do intelectual, para ser mais preciso) partido ao meio, isto é, incompleto, "alienado" - , e que se tornou mais aguda diante dos acontecimentos da Hungria, a ponto de o escritor deixar o partido em 1957. Num artigo de 13 de dezembro de 1980, significativamente intitulado "Quel giorno i carri armati uccisero le nostre speranze" [Naquele dia, os tanques mataram nossas esperanças], referindo-se à possibilidade de transformação do universo socialista que o $\mathrm{XX}$ Congresso do Partido Comunista da União Soviética havia levado a entrever, Calvino, que havia realizado algumas viagens no Leste europeu - Budapeste (1949), Rússia (1951) - e que, no fundo, havia tido uma imagem positiva dos países visitados, ponderava (BARENGHI; FALCETTO, 2011, p. XXI):

Nós, comunistas italianos, éramos esquizofrênicos. Sim, acredito mesmo que esse seja o termo correto. Uma parte de nossos seres era e queria ser testemunha da verdade, 
os vingadores das afrontas sofridas pelos fracos e pelos oprimidos, os defensores da justiça contra todo e qualquer abuso. Outra parte de nossos seres justificava as afrontas, os abusos, a tirania do partido, Stálin, em nome da Causa. Esquizofrênicos. Dissociados. Lembro muito bem que, quando me acontecia de viajar por algum país do socialismo, me sentia profundamente pouco à vontade, alheio, hostil. Mas quando o trem me levava de volta para a Itália, quando tornava a cruzar a fronteira, perguntavame: mas, aqui, na Itália, nesta Itália, o que eu poderia ser senão um comunista? Eis por que o degelo, o fim do stalinismo, tirava um peso terrível de nossas costas: porque nossa imagem moral, nossa personalidade dissociada, finalmente podia recompor-se, finalmente revolução e verdade voltavam a coincidir. Eram estes, naqueles dias, o sonho e a esperança de muitos de nós.

Sonho não realizado e esperança frustrada, porque os rumos da jovem república foram outros; no entanto, não pode ser esquecida a participação ativa das esquerdas na formulação de uma nova constituição nem o papel que elas efetivamente desempenharam na construção da democracia no país. 


\section{Referências}

BARENGHI, M.; FALCETTO, B. “Cronologia”. In: CALVINO, I. L'entrata in guerra. Milano: Mondadori, 2011.

BORGES, A. “A eterna raiva de Pasolini”, 2008. Disponível em: <cinequanon.art.br.>. Acesso em: 13 ago. 2013.

BRUNETTA, Gian Piero. Storia del cinema italiano dal 1945 agli anni ottanta. Roma: Editori Riuniti, 1982.

CALVINO, I. “Apresentação”. In: CALVINO, I. O visconde partido ao meio. São Paulo: Companhia das Letras, 2011.

FERRAZZOLI, M. "Guareschi: e succede un “48”. Disponível em: $<$ www.radicicristiane.it.>. Acesso em: 13 ago. 2013.

JOUBERT-LAURENCIN, H. Pasolini: portrait du poète en cinéaste. Paris: Cahiers du Cinéma, 1995.

MALTESE, C. "Il film-profezia di Pasolini: così nel '63 raccontò l'Italia d'oggi". La Repubblica, 24 ago. 2008. Disponível em: <www. cinetecadibologna.it.> Acesso em: 13 ago. 2013.

MORAVIA, A. "Guicciardini visto da via Veneto". In: MORAVIA, A. Cinema italiano: recensioni e interventi - 1933-1990. Milano: Bompiani, 2010, p. 486-488.

. "Il secondo match tra Fernandel e Cervi". In:

MORAVIA, A. Cinema italiano: recensioni e interventi - 19331990. Milano: Bompiani, 2010, p. 176-179.

"In giacca rossa e parrucca beatnik". In: MORAVIA,

A. Cinema italiano: recensioni e interventi 1933-1990. Milano: Bompiani, 2010, p. 618-619.

"Pasolini nella trappola di Guareschi". In: MORAVIA,

A. Cinema italiano: recensioni e interventi - 1933-1990. Milano: Bompiani, 2010, p. 505-507.

PINTO, F. "Cinema neorealista e política culturale cattolica".

Cinemasessanta, Roma, ano XVI, n. 111, set.-out. 1976.

SILONE, I. "Cronache della steppa”. In: SILONE, I. Le cose per 
cui mi batto: scritti su cultura e politica. Santa Maria Capua Vetere: Edizioni Spartaco, 2004.

TURELLO, M. "I mondi di Pasolini e Guareschi di fronte". Disponível em: <www.pasolini.net.>. Acesso em: 13 ago. 2013. 